\title{
Review of the Improvement Plans on Catenary Systems for Speed Increase in Gyeongbu High-Speed Line
}

\author{
Ki Young Eum, Jangho Yun, Kiwon Lee and Jung Hwan Kim ${ }^{\dagger}$
}

\begin{abstract}
In recent years, the speed of a train has been recognized as one of the important factors to determine the competitiveness as a mean of transportation. In line with this, infrastructure improvements and enhancements are being made with increases in the speed of train. Accordingly, there is a need to establish plans for infrastructure improvements through a comprehensive analysis of signals, track/civil engineering, catenary and environment, etc. to improve the speed of a train of high-speed train service sections in Korea. This study proposes improvement plans for catenary systems by investigating the possibility of improvements through performance analysis of catenary equipment by speed increase based on the analysis on catenary systems in Gyeongbu high-speed line, and analysis the applicability of catenary improvements and economic feasibility.
\end{abstract}

Keywords : Catenary, Economic feasibility, Infrastructure, Gyeongbu high-speed Line

\section{Introduction}

\subsection{Research background}

The speed of a train has recently been recognized as the important factors to determine the competitiveness as a mean of transportation. In particular, the top speed not only has a symbolic meaning that forms the image of transport, but also boosts the self-esteem of people and contribute to the improvement of national competitiveness by showing the technical level of transportation at home and abroad.

Railway is composed of various systems and technologies, so it is required to develop the infrastructure when the speed of a train is up. In japan, a developed country of the train, infrastructure improvements have already been made, along with increase in the speed of the train. Therefore, it is required to establish plans for infrastructure improvements through a comprehensive analysis to improve the speed of

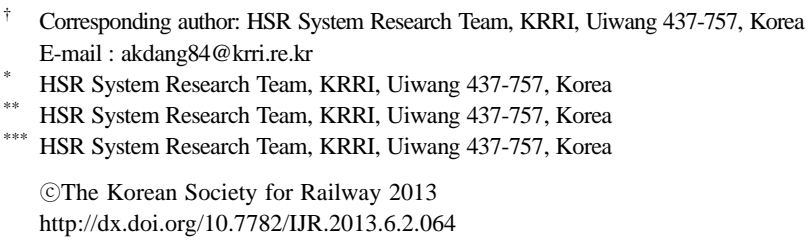

trains of high-speed train service sections in Korea.

In particular, it is necessary to determine whether the system can be applied in each field through interface between infrastructures for review of speed increase, and must analysis the improvement of schedule speed based on TPS(Train Performance Simulation) through comprehensive application of the system between each field. Therefore, since analyzing the improvement of schedule speed on catenary field individually raises the question of equity, the analysis of schedule speed improvement on the plans for catenary system improvement was excluded.

In this regard, this study propose improvement plans of catenary systems through performance analysis of existing catenary equipment by speed increase in Gyeongbu high-speed line and analyzed the applicability of catenary improvements and economic feasibility .

\subsection{Current status of catenary systems}

Since the speed improvement of high-speed line is one of the policy directions promoted at home and abroad, this study investigated the improvement plans of the current catenary system by speed increase in Gyeongbu high-speed line. Especially, it is performed in high-speed track sections in Gyeongbu line as shown in Table 2. 
Ki Young Eum, Jangho Yun, Kiwon Lee, and Jung Hwan Kim / IJR, 6(2), 64-68, 2013

Table 1 Current status of high-speed lines

\begin{tabular}{|c|c|c|c|}
\hline \multicolumn{2}{|c|}{ Segment } & $\begin{array}{c}\text { Gyeongbu } \\
\text { high-speed line }\end{array}$ & $\begin{array}{c}\text { Honam } \\
\text { high-speed line }\end{array}$ \\
\hline \multicolumn{2}{|c|}{ Design speed } & $350 \mathrm{~km} / \mathrm{h}$ & $350 \mathrm{~km} / \mathrm{h}$ \\
\hline \multirow{2}{*}{$\begin{array}{l}\text { Catenary } \\
\text { wire }\end{array}$} & Type & $\begin{array}{l}\text { Grooved trolley wire } \\
\qquad \mathrm{Cu} 150 \mathrm{~mm}^{2}\end{array}$ & $\begin{array}{l}\text { Grooved trolley wire } \\
\text { CuSn } 150 \mathrm{~mm}^{2}\end{array}$ \\
\hline & Tension & $20,000 \mathrm{~N}$ & $26,000 \mathrm{~N}$ \\
\hline \multirow{2}{*}{$\begin{array}{l}\text { Messenger } \\
\text { wire }\end{array}$} & Type & $\mathrm{Bz} 65 \mathrm{~mm}^{2}$ & $\mathrm{Bz} 116 \mathrm{~mm}^{2}$ \\
\hline & Tension & $14,000 \mathrm{~N}$ & $20,000 \mathrm{~N}$ \\
\hline \multirow{2}{*}{ Dropper } & Spacing & $4.5 \mathrm{~m} / 6.75 \mathrm{~m}$ & $4.5 \mathrm{~m} / 6.5 \mathrm{~m}$ \\
\hline & Material & $\mathrm{Bz} 12 \mathrm{~mm}^{2}$ & $\mathrm{Bz} 12 \mathrm{~mm}^{2}$ \\
\hline \multicolumn{2}{|c|}{$\begin{array}{l}\text { Automatic tension } \\
\text { adjusting device }\end{array}$} & $\begin{array}{l}\text { Individual } \\
\text { pulley-type }\end{array}$ & $\begin{array}{l}\text { Individual } \\
\text { pulley-type }\end{array}$ \\
\hline \multicolumn{2}{|c|}{ Contact wire height } & $5,080 \mathrm{~mm}$ & $5,100 \mathrm{~mm}$ \\
\hline \multicolumn{2}{|c|}{ Encumbrance } & $1,400 \mathrm{~mm}$ & $1,400 \mathrm{~mm}$ \\
\hline \multicolumn{2}{|c|}{ Maximum span } & $63 \mathrm{~m}$ & $65 \mathrm{~m}$ \\
\hline \multicolumn{2}{|c|}{ Catenary system } & Simple catenary & Simple catenary \\
\hline
\end{tabular}

Table 2 Current status of routes in Gyeongbu line

\begin{tabular}{|c|c|c|c|c|}
\hline $\begin{array}{c}\text { General } \\
\text { track }\end{array}$ & $\begin{array}{l}\text { Seoul } \\
\text { Siheung }\end{array}$ & $\begin{array}{l}\text { Dajeon } \\
\text { Panam }\end{array}$ & $\begin{array}{l}\text { Sangri } \\
\text { Daegu }\end{array}$ & $\begin{array}{l}\text { Entry part of } \\
\text { Busan Staion }\end{array}$ \\
\hline Distance $[\mathrm{km}]$ & 19.183 & 11.335 & 13.694 & 0.38 \\
\hline Design speed & 150 & 150 & 150 & 150 \\
\hline $\begin{array}{l}\text { Operation } \\
\text { speed }\end{array}$ & 135 & 135 & 135 & 135 \\
\hline $\begin{array}{l}\text { High-speed } \\
\text { track }\end{array}$ & $\begin{array}{l}\text { Siheung } \\
\text { Dajeon }\end{array}$ & $\begin{array}{l}\text { Panam } \\
\text { Sangri }\end{array}$ & $\begin{array}{c}\text { Daegu } \sim \\
\text { Busan Station }\end{array}$ & \multirow{4}{*}{$\begin{array}{c}\text { Disance } \\
\text { Of } \\
\text { - high-speed } \\
\text { track } \\
(376.9 \mathrm{~km})\end{array}$} \\
\hline Distance $[\mathrm{km}]$ & 134.435 & 115.123 & 127.369 & \\
\hline Design speed & 350 & 350 & 350 & \\
\hline $\begin{array}{l}\text { Operation } \\
\text { speed }\end{array}$ & 350 & 300 & 300 & \\
\hline
\end{tabular}

\section{Catenary System Improvement Plans and Economic Analysis}

\section{1 review directions}

In this study, the maximum operation speed of Gyeonbu high-speed line section was examined first, and then the increase in tension due to the catenary wave propagation velocity and life of catenary was investigated. Lastly, improvement plans for catenary equipment was established in terms of economic efficiency and maintainability.

\section{2 review on the maximum operation speed of high-speed line}

According to the government's basic plans, the design speed of Gyeongbu high-speed line is $350 \mathrm{~km} / \mathrm{h}$, and the maximum operation speed is $300 \mathrm{~km} / \mathrm{h}$ as shown in Table 2 .
Table 3 International standards(EN \& UIC)

\begin{tabular}{c}
\hline EN 50119(2001) \\
\hline Operation speed is less than $70 \%$ of C \\
\hline UIC CODE 799-OR $(2002)$ \\
${ }^{*} \mathrm{C}:$ wave propagation velocity $[\mathrm{km} / \mathrm{h}]$
\end{tabular}

Table 4 Reinterpretation of design speed on Gyeongbu line

\begin{tabular}{cl}
\hline International standards & \multicolumn{1}{c}{ Calculation } \\
\hline EN 50119 & $\rightarrow$ Operation speed $=441 \times 70 \%$ \\
$(2001)$ & $\rightarrow$ Operation speed $\fallingdotseq 309 \mathrm{~km} / \mathrm{h}$ \\
\hline & $\rightarrow \mathrm{C}=308 \mathrm{~km} / \mathrm{h}+144 \mathrm{~km} / \mathrm{h}$ \\
UIC CODE 799-OR & $\rightarrow \mathrm{C}=452 \mathrm{~km} / \mathrm{h}$ \\
$(2002)$ & $\rightarrow 308 \div 452=0.68$ \\
& $\rightarrow$ Design speed $\fallingdotseq 70 \%$ of C \\
\hline
\end{tabular}

${ }^{*} \mathrm{C}$ of Gyeongbu high-speed line $\left(\mathrm{Cu} 150 \mathrm{~mm}^{2}\right)=441 \mathrm{~km} / \mathrm{h}$

However, discrepancies of the basic plans were found, and problems of the interpretation of terms were raised by the technical review committee for selecting catenary system of Honam high-speed line in 2008. In a rated move, the following amendment(article 2 of railway construction rules) was completed in 2009. "Design speed refers to the speed limit that serves as a criterion when designing the track.

With the change in definition of design speed, the maximum operation speed of Gyeongbu and Honam highspeed line according to the wave propagation velocity(C) was reinterpreted based on the international standards of EN and UIC CODE as shown in Table 3.

2.2.1 reinterpretation of design speed in Gyeongbu highspeed line

The design speed of $350 \mathrm{~km} / \mathrm{h}$ was applied to high-speed line at the beginning. However, according to the change in definition of design speed and international standards of $\mathrm{C}$, operation speed for stable operation of the train was determined to be $70 \%$ of C. From the results of the calculation as shown in Table 4, $308 \mathrm{~km} / \mathrm{h}$ was selected as the maximum operation speed(design speed) of Gyeongbu high-speed line.

2.2.2 reinterpretation of design speed in Honam highspeed line

The design speed of $350 \mathrm{~km} / \mathrm{h}$ was also applied to Honam high-speed line at the beginning as shown in Table 1. As above, $70 \%$ of wave propagation velocity of Honam highspeed line was determined to be suitable. From the results of the calculation as shown in Table $5,350 \mathrm{~km} / \mathrm{h}$ was selected as the maximum operation speed of Honam high-speed line. 
Table 5 Reinterpretation of design speed on Honam line

\begin{tabular}{cl}
\hline International standards & \multicolumn{1}{c}{ Calculation } \\
\hline EN 50119 & $\rightarrow$ Operation s peed $=502 \times 70 \%$ \\
$(2001)$ & $\rightarrow$ Operation speed $\fallingdotseq 351 \mathrm{~km} / \mathrm{h}$ \\
\hline & $\rightarrow \mathrm{C}=308 \mathrm{~km} / \mathrm{h}+144 \mathrm{~km} / \mathrm{h}$ \\
UIC CODE 799-OR & $\rightarrow \mathrm{C}=494 \mathrm{~km} / \mathrm{h}$ \\
$(2002)$ & $\rightarrow 350 \div 494=0.708$ \\
& $\rightarrow$ Design speed $\fallingdotseq 70 \%$ of C \\
\hline
\end{tabular}

${ }^{*} \mathrm{C}$ of Honam high-speed line $\left(\mathrm{CuSn} 150 \mathrm{~mm}^{2}\right)=502 \mathrm{~km} / \mathrm{h}$

Table 6 Review on tension of catenary by speed increase

\begin{tabular}{|c|c|c|c|}
\hline $\begin{array}{l}\text { Speed } \\
\text { increase }\end{array}$ & calculation & $308 \mathrm{~km} / \mathrm{h} \quad 310 \mathrm{~km} / \mathrm{h}$ & $320 \mathrm{~km} / \mathrm{h}$ \\
\hline $\mathrm{C}$ & $\begin{array}{l}\rightarrow \mathrm{V}_{\max }=\mathrm{C} \times 70 \% \\
\rightarrow \mathrm{C}=\mathrm{V}_{\max } \div 70 \%\end{array}$ & $441 \mathrm{~km} / \mathrm{h} \quad 443 \mathrm{~km} / \mathrm{h}$ & $457 \mathrm{~km} / \mathrm{h}$ \\
\hline$T_{0}$ & $\begin{array}{l}\rightarrow \mathrm{C}=3.6 \times \sqrt{\frac{T_{0}}{\rho}} \% \\
\rightarrow T_{0}=\frac{C^{2} \times \rho}{3.6^{2}}\end{array}$ & $20,000 \mathrm{~N} \quad 20,200 \mathrm{~N}$ & $21,500 \mathrm{~N}$ \\
\hline
\end{tabular}

$* \mathrm{~V}_{\max }:$ Maximum operation speed $[\mathrm{km} / \mathrm{h}]$,

$T_{0}:$ Standard tension of catenary[N]

$\rho:$ Unit mass of catenary $[1.334 \mathrm{~kg} / \mathrm{m}]$

Table 7 Review on tension of catenary by speed increase

\begin{tabular}{|c|c|c|c|}
\hline $\begin{array}{c}\text { Speed } \\
\text { increase }\end{array}$ & calculation & $308 \mathrm{~km} / \mathrm{h} 310 \mathrm{~km} / \mathrm{h}$ & $320 \mathrm{~km} / \mathrm{h}$ \\
\hline A & $\begin{array}{l}\rightarrow T_{a}=\frac{\sigma \times A}{s} \\
\rightarrow A=\frac{T_{a} \times s}{\sigma}\end{array}$ & $\begin{array}{c}138.5 \mathrm{~mm}^{2} 139.8 \mathrm{~mm}^{2} \\
(\mathrm{D}: 11.8) \quad(\mathrm{D}: 12)\end{array}$ & $\begin{array}{c}148.9 \mathrm{~mm}^{2} \\
(\mathrm{D}: 12.7)\end{array}$ \\
\hline $\begin{array}{c}\text { Allowable } \\
\text { wear amount }\end{array}$ & $\begin{array}{l}\mathrm{Cu} 150 \mathrm{~mm}^{2} \\
\text { (D:13.6 mm) }\end{array}$ & $1.6 \mathrm{~mm}$ & $0.9 \mathrm{~mm}$ \\
\hline
\end{tabular}

${ }^{*} T_{a}$ : Allowable tensile force[N], $\sigma$. Breaking load[336.6 N/mm²]

A : Allowable cross section[mm²], S: Safety rate(2.2)

D: Residual diameter[mm]

*In this case, $T_{a}$ is calculated by adding suppression resistance of $5 \%$

\subsection{Plans for speed increase of Gyeongbu high-speed line}

For improvement of speed increase of Gyeongbu highspeed line, the life of catenary, wear amount of catenary and compatibility, wave propagation velocity by speed increase $(308 \mathrm{~km} / \mathrm{h}, 310 \mathrm{~km} / \mathrm{h}, 320 \mathrm{~km} / \mathrm{h})$ was calculated

\subsubsection{Review of tension and life by speed increase}

First, the maximum operation speed of the train was set to $308 \mathrm{~km} / \mathrm{h}, 310 \mathrm{~km} / \mathrm{h}$ and $320 \mathrm{~km} / \mathrm{h}$, and then tension which is appropriate to the speed was calculated by figuring out the required wave propagation velocity as shown
Table 8 The wear rate measurement Data of catenary

\begin{tabular}{|c|c|c|c|c|}
\hline $\begin{array}{c}\text { Time of } \\
\text { measurement }\end{array}$ & $\begin{array}{l}\text { Type of } \\
\text { wire }\end{array}$ & $\begin{array}{l}\text { Measurement } \\
\text { value }\end{array}$ & Wear value & $\begin{array}{l}\text { Cumulative } \\
\text { ware value }\end{array}$ \\
\hline 2006 year & \multirow{4}{*}{$\begin{array}{c}\mathrm{Cu} \\
150 \mathrm{~mm}^{2}\end{array}$} & $13.43 \mathrm{~mm}$ & $0.17 \mathrm{~mm}$ & $0.17 \mathrm{~mm}$ \\
\hline 2007 year & & $13.28 \mathrm{~mm}$ & $0.15 \mathrm{~mm}$ & $0.32 \mathrm{~mm}$ \\
\hline 2008 year & & $13.16 \mathrm{~mm}$ & $0.12 \mathrm{~mm}$ & $0.44 \mathrm{~mm}$ \\
\hline 2009 year & & $13.12 \mathrm{~mm}$ & $0.04 \mathrm{~mm}$ & $0.48 \mathrm{~mm}$ \\
\hline & rage wea & $r$ amount per $y$ & & $0.096 \mathrm{~mm}$ \\
\hline
\end{tabular}

*The Contact wire value record shows measurement results after the opening on April 1, 2004, and it was obtained from Osong Electricity Office of the Korea Railroad Corporation.

Table 9 The predicted life of catenary by speed increase

\begin{tabular}{cccc}
\hline Speed increase & $308 \mathrm{~km} / \mathrm{h}$ & $310 \mathrm{~km} / \mathrm{h}$ & $320 \mathrm{~km} / \mathrm{h}$ \\
\hline Allowable wear amount & $1.8 \mathrm{~mm}$ & $1.6 \mathrm{~mm}$ & $0.9 \mathrm{~mm}$ \\
\hline Predicted life & 19 years & 17 years & 9 years
\end{tabular}

*Calculation, ex $)$ Wear amount $(1.6 \mathrm{~mm}) \div$ average wear amount per year $(0.096 \mathrm{~mm}) \fallingdotseq 17$ years

Table 10 Review results by speed increase

\begin{tabular}{cccc}
\hline Speed increase & $308 \mathrm{~km} / \mathrm{h}$ & $310 \mathrm{~km} / \mathrm{h}$ & $320 \mathrm{~km} / \mathrm{h}$ \\
\hline Wave propagation velocity & $441 \mathrm{~km} / \mathrm{h}$ & $443 \mathrm{~km} / \mathrm{h}$ & $457 \mathrm{~km} / \mathrm{h}$ \\
\hline Allowable wear amount & $1.8 \mathrm{~mm}$ & $1.6 \mathrm{~mm}$ & $0.9 \mathrm{~mm}$ \\
\hline Predicted life & 19 years & 17 years & 9 years \\
\hline Catenary tension & $20 \mathrm{KN}$ & $20.2 \mathrm{KN}$ & $21.5 \mathrm{KN}$ \\
\hline
\end{tabular}

in Table 6.

Second, since catenary $\left(\mathrm{Cu} 150 \mathrm{~mm}^{2}\right)$ takes the form of polygon, not circle, it is difficult to calculate cross-sectional area and residual diameter. Accordingly, the remaining cross-sectional area was calculated with standard tension set, and the residual diameter was calculated using a CAD Program as shown in Table 7.

Lastly, Table 9 shows the life of catenary which was predicted based on the wear rate measurement during 4 years of use after the opening of Gyeongbu high-speed line in 2004 as shown in Table 8. However, the actual life of catenary replacement may vary depending on the type of train operation in case of the life of catenary in this section.

2.3.2 Review results and improvement plans by speed increase

From the review results as shown in Table 10, $308 \mathrm{~km} / \mathrm{h}$ was selected as the maximum operation speed(design speed) for Gyeongbu high-speed line, and $350 \mathrm{~km} / \mathrm{h}$ for Honam high-speed line respectively.

Since $308 \mathrm{~km} / \mathrm{h}$ is the current maximum operation speed of Gyeongbu high-speed line, it doesn't require improve- 
Ki Young Eum, Jangho Yun, Kiwon Lee, and Jung Hwan Kim / IJR, 6(2), 64-68, 2013

Table 11 The improvement plans by speed increase

\begin{tabular}{|c|c|c|}
\hline \multirow{2}{*}{\multicolumn{2}{|c|}{ Segment }} & Train operation speed \\
\hline & & $320 \mathrm{~km} / \mathrm{h}$ \\
\hline \multicolumn{2}{|c|}{ Catenary wire } & No change No change Replacement \\
\hline \multicolumn{2}{|c|}{ Messenger wire } & No change No change Replacement \\
\hline \multirow{2}{*}{ Tension } & Catenary & Adjustment Adjustment \\
\hline & Messenger & No change Adjustment \\
\hline \multicolumn{2}{|c|}{ Tension adjusting device } & No change ImprovementImprovement \\
\hline \multirow{2}{*}{ Dropper } & Spacing & Adjustment Replacement \\
\hline & Material & No change Replacement \\
\hline \multicolumn{2}{|c|}{ Railway electric pole } & No change No change No change \\
\hline \multicolumn{2}{|c|}{ Catenary height } & No change No change \\
\hline \multicolumn{2}{|c|}{ Other ancillary velocity } & No change Adjustment Replacement \\
\hline \multirow{3}{*}{$\begin{array}{l}\text { Review } \\
\text { comments }\end{array}$} & $308 \mathrm{~km} / \mathrm{h}$ & The current maximum operation speed \\
\hline & $310 \mathrm{~km} / \mathrm{h}$ & Need to review the life \\
\hline & $320 \mathrm{~km} / \mathrm{h}$ & Applied to Honam high-speed line \\
\hline
\end{tabular}

ment of catenary equipment as shown in Table 11 .

In case of speed increase to $310 \mathrm{~km} / \mathrm{h}$, a similarity exists between the life of existing catenary and wave propagation velocity, but there is a need for tension adjustment, improved tensioning device, dropper adjustment and adjustment of other ancillary equipment.

In case of speed increase to $320 \mathrm{~km} / \mathrm{h}$, the life of catenary is less than 10 years, which is disadvantage in terms of maintenance, and excessive expenditure of maintenance costs due to the reduced life is expected.

In this context, in case of speed increase up to more than $320 \mathrm{~km} / \mathrm{h}$, it would be appropriate to make improvements through Honam high-speed line system which is under construction after its development by "A study on the technology development for $350 \mathrm{~km} / \mathrm{h}$-grade catenary system”.

\subsection{Economic analysis of catenary field by speed increase}

An analysis on economic efficiency of system improvements in catenary field according to the distance of highspeed line in case of speed increase by $308 \mathrm{~km} / \mathrm{h}, 310 \mathrm{~km} /$ $\mathrm{h}$ and $320 \mathrm{~km} / \mathrm{h}$ was conducted based on the construction unit cost standards of the Korea Rail Network Authority and construction costs of catenary in Gyeongbu highspeed line as shown in Table 12.

As its results, it was found that economic efficiency is low due to the construction costs of the improvements of existing systems. It is expected that in the case of $310 \mathrm{~km} / \mathrm{h}$, improvement can be achieved by partial adjustment of the power supply-off time for the existing operation lines, but overall improvement according to the speed increase up to
Table 12 The Approximate construction costs by speed increase

\begin{tabular}{|c|c|c|}
\hline $\begin{array}{c}\text { Speed } \\
\text { increase }\end{array}$ & Facility improvements & $\begin{array}{c}\text { Approximate } \\
\text { construction costs } \\
\text { [won] }\end{array}$ \\
\hline $\begin{array}{c}308 \\
{[\mathrm{~km} / \mathrm{h}]}\end{array}$ & - No change & - \\
\hline $\begin{array}{c}310 \\
{[\mathrm{~km} / \mathrm{h}]}\end{array}$ & $\begin{array}{c}\text { - Tension adjustment } \\
\text { - Improved tension adjusting device } \\
\text { - Dropper spacing adjustment } \\
\text { - Adjustment of other ancillary } \\
\text { equipment }\end{array}$ & $\begin{array}{c}10.2 \\
\text { billion }\end{array}$ \\
\hline $\begin{array}{c}320 \\
{[\mathrm{~km} / \mathrm{h}]}\end{array}$ & $\begin{array}{c}\text { - Tension adjustment } \\
\text { - Replacement of catenary and } \\
\text { messenger } \\
\text { - Improved tension adjusting device } \\
\text { - Dropper spacing and material } \\
\text { replacement } \\
\text { - Change of catenary height } \\
\text { - Replacement of other ancillary } \\
\text { equipment }\end{array}$ & $\begin{array}{c}277.5 \\
\text { billion }\end{array}$ \\
\hline
\end{tabular}

more than $320 \mathrm{~km} / \mathrm{h}$ will lead to disadvantageous results due to the increase in construction costs and hindrance of railway operation.

\section{Conclusion}

This study proposed improvement plans for catenary systems by investigating the possibility of improvements through performance analysis of catenary equipment by speed increase based on the analysis on catenary systems of Gyeongbu high-speed line, and analyzed the applicability of catenary improvements and economic efficiency.

First, the maximum operation speed of Gyeongbu highspeed line was determined to be $308 \mathrm{~km} / \mathrm{h}$ according to the change in definition of design and international standards of wave propagation velocity.

Second, concerns about material supply of tension weight due to an increase in tension are raised in case of speed increase to $310 \mathrm{~km} / \mathrm{h}$, but facility improvement can be made. However, since an increase in tension of the catenary is inevitable in case of the speed increase, and separation ratio and contact force of the catenary due to the increase in tension cannot be verified, a verification through a current-collection performance simulation is required. In case of the catenary $\mathrm{Cu} 150 \mathrm{~mm}^{2}$, a verification need to be conducted through empirical experiments since there exist no operation results in more than $20 \mathrm{KN}$. In addition, the prediction of life may lead to flexible outcomes due to the lack of accurate data. 
Third, the life of catenary was estimated to be less than 10 years in case of speed increase to $320 \mathrm{~km} / \mathrm{h}$, which indicates that improvements by as increase in tension of the existing systems are not valid in terms of economy and maintenance, and the overall improvement of catenary was found to be disadvantageous due to the increase in construction costs and hindrance of railway operation.

Fourth, it would be appropriate to make improvements through Honam high-speed line systems of $350 \mathrm{~km} / \mathrm{h}$ grade in case of speed increase up to more than $350 \mathrm{~km} / \mathrm{h}$.

Thus, in the case of speed increase of Gyeongbu highspeed line, the effects of speed increase due to the improvement of catenary system can be anticipated, but an analysis shows that there are practical difficulties in the overall improvement of systems and the final determination of improvement plans through a validation study of ancillary systems. In addition, since the train load increases in case of the high-speed operation of trains, there is a need to review the adequacy of the transformer capacity and voltage drop through a power flow simulation on the basis of the train operation plans.

\section{Acknowledgement}

This study was carried out as part of the research titled,
"Development of technology for a trial application of $400 \mathrm{~km} / \mathrm{h}$-grade high-speed rail infrastructure" supported by the ministry of Land, Transport and Maritime Affair.

\section{References}

1. Korea Railroad Research Institute, "Report on the overall high-speed rail infrastructure and interface research", 2002.

2. Korea Railroad Research Institute, "Development of improved technology of the line system for improving speed", 2005.

3. Korea Rail Network Authority, "Final report on plans for establishment of signal system by stage according to the speed-up of railway construction lines", 2011.

4. Korea Rail Network Authority, "Report on the design of Gyeongbu high-speed line(Step 1, Step 2) ", 2006.

5. Korea Railroad Research Institute, "Final report on development of technologies for rail system improvement for speed increase of existing lines( $4^{\text {th }}$ years)", 2005.

6. Seoyeong ENG, "Study analysis in the field of track by improving scheduled speed", 2011.

7. Korea Railroad Research Institute, "Report on reinforcement cost research of infrastructure by improving operating speed of high-speed train", 2010.

8. Overseas Railway Technology Cooperative, "Speed increase of shinkansen", P11-46, 2008. 